\title{
Analysis on the Impact of the Foreign Exchange Reserves of China on Its Macro Economy
}

\author{
Jiahao Zhang ${ }^{1, \text { a }}$ \\ ${ }^{1}$ College of mathematics, Sichuan University, Chengdu, Sichuan, 610065, China
}

\begin{abstract}
China has the largest foreign exchange reserve in the world, but the high foreign exchange reserve is a double-edged sword for the country. There are two kinds of analysis for this. First, China's foreign exchange reserves have far exceeded the reasonable scale, which will cause China to pay extremely high management costs. Second, China's foreign exchange reserves are considerable, but this is the objective demand of the economy. Sufficient foreign exchange reserves can make China occupy a favorable position in international development. Based on the data on China's foreign exchange reserve, foreign debt scale and GDP from 1985 to 2019, this paper analyzes the positive and negative effects of high foreign exchange reserve on China's economic development. By analyzing the current situation of China's foreign exchange, the author gives some policy suggestions: (1) appropriately reduce foreign exchange reserves; (2) promote the reform of the exchange rate system; (3) reform the foreign exchange system
\end{abstract}

\section{INTRODUCTION}

Foreign exchange reserve is the foreign exchange part of a country's reserve assets. It is a creditor's right held by a country's Government in foreign currency, and also an asset held by a country's monetary authority that can be exchanged for foreign currency at any time. Together with gold reserve, special drawing right and money that a country can use at any time in the International Monetary Fund, it constitutes the country's reserve assets. In a narrow sense, foreign exchange reserve is an important part of a country's economic strength, which is used to balance the balance of payments, stabilize the exchange rate and repay foreign debts. In a broad sense, foreign exchange reserves refer to assets denominated in foreign exchange, including cash, foreign bank deposits, foreign securities, etc.

However, foreign exchange reserves are not the more the better. In recent years, China's foreign exchange reserves of such a huge scale also have some negative effects on China's economic development. Therefore, it is of great significance to find out the influencing factors of China's foreign exchange reserves in combination with China's specific national conditions for the study of the appropriate scale of China's foreign exchange reserves and the management of foreign exchange reserves.

The specific problems that this paper wants to study are as follows: (1). The cause of China's high foreign exchange reserves. (2). The moderation analysis of the scale of China's foreign exchange reserves. This paper first describes the current situation of China's high foreign exchange reserves and then analyzes the causes of China's high foreign exchange reserves. By collecting the chart data of China's foreign exchange reserves and their growth volume and growth rate from 1985 to 2018, combined with the data of China's foreign exchange reserves on the official website of China foreign exchange administration, it is found that the scale of China's foreign exchange reserves has changed dramatically, and China's foreign exchange has experienced a process from slow growth to rapid growth.

\section{CURRENCT SITUATION OF THE FOREIGN EXCHANGE RESERVES OF CHINA}

After the reform and opening up, with the rapid development of China's economy, the scale of China's foreign exchange reserves also grows rapidly. Table 1 shows the changes of China's foreign exchange reserves, its growth volume and growth rate from 1990 to 2018. As can be seen from the data in the table, the scale of China's foreign exchange reserves has changed dramatically. From 1985 to 2018, an increase is of nearly 1200 times. However, it can be seen from Figure 1 that this change is not a sudden change, but a process from slow growth to rapid growth. 


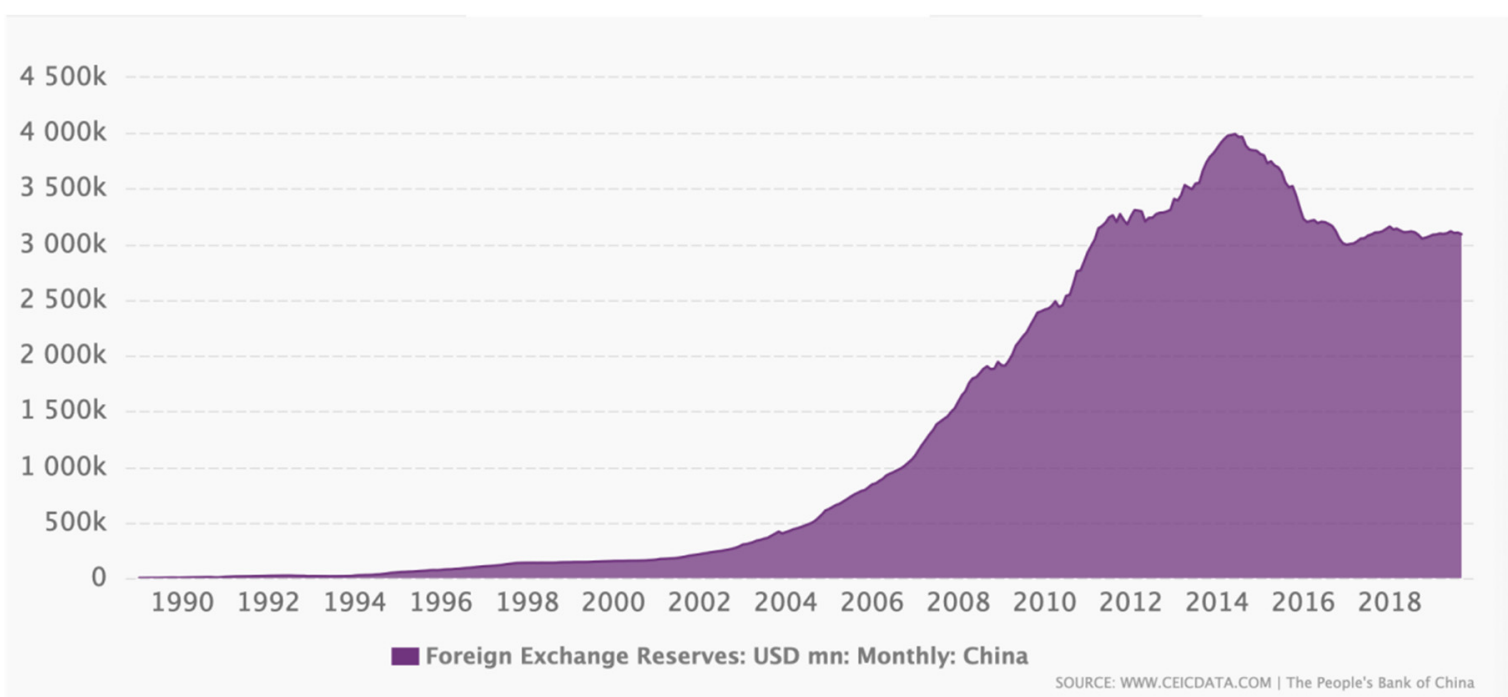

Figure 1. Foreign Exchange Reserves.

The foreign exchange reserves in China stood at only US\$ 840 million in 1979, and it experienced slow annual growth except one or two years during the 1980s. However, since 1994, when the reform of foreign exchange management system was launched, foreign exchange reserves of China had rapidly increased from US\$21.199 billion to US\$ 15.4675 billion at the end of the 1999 , and the average chain growth rate was $39.27 \%$, exceeding the growth rate of GNP in the same period. In the following 5 years (2000-2004) which was a second high growth period, China's foreign exchange reserves grew even more amazingly. And in Figure 2, we can see in 2000, the foreign exchange reserve was US\$ 165.574 billion, while at the end of the 2004, it increased to the US\$ 609.932 billion, and the annual increase was $28.14 \%, 34.99 \%, 40.80 \%$ and $51.25 \%$ respectively [1]. By the end of 2002, China's total foreign exchange reserves were only the second largest in the world after Japan. Since then, it has maintained a high growth rate and growth rate, with an average annual increase of 321638 million US dollars. At the end of 2006, China's total foreign exchange reserves reached 1066.344 billion
US dollars, breaking the 1 trillion mark for the first time [2]. Later, affected by the international financial crisis triggered by the sub prime mortgage crisis in 2008 , the world's economies, including China's major trading partners, were greatly impacted, and China's exports were affected. Since then, the growth of China's foreign exchange reserves has slowed down. However, due to the fact that it still keeps growing, ranking first in the world. In 2014, the foreign exchange reserves will continue to be reduced until 2016. There are two important reasons. First, it has a lot to do with the overall global situation. Due to the impact of the Fed's expectation of interest rate hike, non US currencies with stronger US dollar fell sharply, and the RMB was also under the influence. The particularity is that the RMB is in the transition stage of internationalization. In order to prevent panic selling caused by sharp decline, the central bank must use external reserves to stabilize the RMB exchange rate. Second, it is related to the export surplus. Due to the influence of weak global consumption, the ability of export to generate foreign exchange has declined, which makes the increase of foreign exchange reserves shrink.

Table 1. Data of China's foreign exchange reserves.

\begin{tabular}{c|c|c|c}
\hline Particular year & $\begin{array}{c}\text { National foreign exchange reserves } \\
\text { (US \$100 million) }\end{array}$ & $\begin{array}{c}\text { Increment (US \$100 } \\
\text { million) }\end{array}$ & $\begin{array}{c}\text { Growth rate of national foreign } \\
\text { exchange reserves (\%) }\end{array}$ \\
\hline 1985 & 26.44 & -55.76 & -67.8345 \\
\hline 1986 & 20.72 & -5.72 & -21.6339 \\
\hline 1987 & 29.23 & 8.51 & 41.0714 \\
\hline 1988 & 33.72 & 4.49 & 15.3609 \\
\hline 1989 & 55.5 & 21.78 & 64.5907 \\
\hline 1990 & 110.93 & 55.43 & 99.8739 \\
\hline 1991 & 217.12 & 106.19 & -10.4504 \\
\hline 1992 & 194.43 & -22.69 & 9.0315 \\
\hline 1993 & 211.99 & 17.56 & 143.5021 \\
\hline 1994 & 516.2 & 304.21 & 42.5746 \\
\hline 1995 & 735.97 & 219.77 & 42.7083 \\
\hline 1996 & 1050.29 & 314.32 & 33.1918 \\
\hline 1997 & 1398.9 & 348.61 & 3.6236 \\
\hline
\end{tabular}




\begin{tabular}{c|c|c|c}
\hline 1999 & 1546.75 & 97.16 & 6.7026 \\
\hline 2000 & 1655.74 & 108.99 & 7.0464 \\
\hline 2001 & 2121.65 & 465.91 & 34.1391 \\
\hline 2002 & 2864.07 & 742.42 & 40.7965 \\
\hline 2003 & 4032.51 & 1168.44 & 51.2537 \\
\hline 2004 & 6099.32 & 2066.81 & 34.2563 \\
\hline 2005 & 8188.72 & 2089.4 & 30.2211 \\
\hline 2006 & 10663.44 & 2474.72 & 43.3167 \\
\hline 2007 & 15282.49 & 4619.05 & 27.3372 \\
\hline 2008 & 19460.3 & 4177.81 & 23.2844 \\
\hline 2009 & 23991.52 & 4531.22 & 18.681 \\
\hline 2010 & 28473.38 & 4481.86 & 11.7236 \\
\hline 2011 & 31811.48 & 3338.1 & 4.1004 \\
\hline 2012 & 33115.89 & 1304.41 & 15.392 \\
\hline 2013 & 38213.15 & 5097.26 & 0.5679 \\
\hline 2014 & 38430.18 & 217.03 & -13.339 \\
\hline 2015 & 33303.62 & -5126.56 & -9.6038 \\
\hline 2016 & 30105.17 & -3198.44 & 4.299 \\
\hline 2017 & 31399.49 & 1294.32 & -2.141 \\
\hline 2018 & 30727 & -672.49 & 1.1455 \\
\hline 2019 & 31079 & 352 & \\
\hline
\end{tabular}

Data source: Official Website of China Foreign Exchange Administration

\section{AN ANALYSIS OF THE CURRENT SITUATION AND CAUSES OF CHINA'S HIGH FOREIGN EXCHANGE RESERVES}

\subsection{Domestic reasons}

\subsubsection{The government's policy orientation}

China's balance of payments is unbalanced and its foreign exchange reserves are growing, which is not formed overnight. Basically, it is caused by the export-oriented policies, preferential policies for foreign investment and imperfect market mechanism in the past 25 years. On the issue of balance of payments, the long-term policy of the Chinese government is that there is a slight surplus in the basic balance of payments; for a long time, the Chinese government has paid more attention to the function of foreign exchange reserves, believing that the more foreign reserves we have, the better, we must not use them easily unless we have to. In terms of foreign exchange policy, the system of compulsory settlement, sale and exchange is implemented. At the same time, due to the long-term implementation of the export-oriented, foreign-funded and foreign exchange policy of "wide in and strict out" orientation since the reform and opening up, capital flow is relatively easy, while outflow needs to be approved at all levels, resulting in a large number of current account surpluses and increasing FDI flow.

\subsubsection{The contradiction between rapid economic development and lagging structural adjustment}

On October 19, 2007, Wu Xiaoling delivered a speech at the seminar on China's exchange rate policy sponsored by Peterson Institute of international economics. He said that the high surplus of China's foreign trade is a reflection of China's internal economic imbalance, which is caused by the structural problems of high savings, high investment and low consumption [3]. In the past 20 years, supported by high savings rate and high investment rate, the average annual growth rate of China's economy has exceeded $9 \%$. At the same time, profound changes have taken place in the economic structure. However, due to historical and institutional reasons, the pace of structural adjustment is often lagging behind. Especially in recent years, after the basic living needs of domestic residents have been met and the industrial development has reached a new level, the commodity, capital and labor markets are all in surplus. The production structure can not adapt to the changes of demand structure, and can not meet the needs of many kinds and levels, resulting in the lack of effective aggregate demand, and further resulting in employment difficulties and weak demand growth.

\subsubsection{Insufficient flexibility of domestic exchange rate system}

Since January 1, 1994, the State Council has decided to further reform China's foreign exchange management system. The exchange rate of RMB has been integrated and a "single managed floating exchange rate system based on market supply and demand" has been implemented. However, the outbreak of the Asian financial crisis in 1997 hindered the reform of the RMB exchange rate system. The RMB exchange rate encountered strong devaluation pressure. In order to maintain the stability of the RMB exchange rate, the arrangement of the RMB exchange rate system was forced to deviate from the original intention of the "managed floating exchange rate system", and gradually changed into a fixed exchange rate system pegged to the US dollar. Due to the strict foreign exchange control in China for a long time, according to the classification of IMF exchange rate system, compared with other countries, China's exchange rate system is still inelastic. 


\subsection{International reasons}

\subsubsection{Economic globalization and global industrial transfer and structural adjustment}

Economic globalization, global industrial transfer and structural adjustment are the main reasons for China's sustained balance of payments surplus and increasing foreign exchange reserves. In recent years, the global economic downturn and the global high-tech bubble burst have further accelerated global structural adjustment and industrial transfer. At the same time, with the continuous expansion of China's opening up, the rich domestic human resources, and the increasingly perfect infrastructure and legal environment, China has gradually become one of the main destinations of international manufacturing industry transfer. A large trade surplus makes the foreign exchange reserve increase year by year, even at present it is in a high state.

\subsubsection{Expected factors of RMB appreciation}

In recent years, the U.S. dollar continues to depreciate significantly, which puts a huge pressure on many Asian currencies that are pegged to the U.S. dollar or have a high proportion of the U.S. dollar in the currency basket, especially the RMB, which will exert a domino effect on the appreciation of Asian currencies. Especially since July 21, 2005, the people's Bank of China officially announced the implementation of the floating exchange rate system with the market as the adjustment mechanism, the RMB is constantly releasing its flexibility. In the past two years, the cumulative appreciation of RMB against the US dollar has exceeded $10 \%$.

A huge amount of international hot money has entered the domestic market through various channels, which has set off a round of RMB speculation. For one thing, the rapid growth of foreign exchange reserves leads to the expectation of RMB appreciation. For another, the formation of the expectation of RMB appreciation encourages the increase of foreign exchange reserves. Because foreign investors have strong expectations for the appreciation of the RMB, a lot of hot money has flowed into the capital market, causing the stock market bubble. At the same time, due to the expectation of the appreciation of RMB by foreign investors, the investment is all inward flow, while the domestic investors should have diversified their asset portfolio and could flow their capital to Japan, the United States, Europe and other places, but the appreciation of RMB has led to the improvement of the expectation of return of domestic stock market, and the restriction of investment abroad, the domestic stock market has become the main investment objective This also aggravates the formation of asset bubbles in China.

\section{ANANLYSIS OF THE SCALE OF CHINA'S FOREIGN EXCHANGE RESERVEST}

High foreign exchange reserves have strengthened China's ability to adjust its balance of payments. When changes in the international market lead to sharp decline in exports or structural imbalances in the balance of payments, and urgent or long-term adjustments are needed, the state can use sufficient foreign exchange reserves to adjust, so as to mitigate the external impact of adjustment, thus reducing the adverse impact on the economy caused by emergency measures, and promoting the stable development of the national economy. At the same time, it has strengthened China's macro-control ability to the economy. China's high foreign exchange reserves have strengthened the confidence and ability of the state to adjust the balance of payments by means of indirect regulation, maintain the stability of $\mathrm{RMB}$ exchange rate, and create conditions for China to make full use of domestic and international markets and domestic and international resources, so that China can accelerate the process of domestic reform and opening up. China will strengthen our ability to attract foreign investment and foreign financing. Holding sufficient foreign exchange reserves can not only meet the needs of repayment of principal and interest during the peak period of debt repayment, but also provide necessary conditions and guarantees for maintaining China's good reputation in the world, attracting foreign investment and striving for international advantages. China's abundant foreign exchange reserves have promoted the free exchange of RMB. At present, China's sufficient foreign exchange reserves enhance the confidence of the international and domestic in the RMB, make the RMB closer to the "hard currency", and lay a good foundation for the central bank to effectively regulate the foreign exchange market, maintain the basic balance of the balance of payments, keep the basic stability of the exchange rate in the process of moving towards free exchange, and finally realize the free exchange of the RMB.

However, foreign exchange reserves are not the more the better. Nowadays, China's huge foreign exchange reserves have had some negative effects on China's economic development. High foreign exchange reserves waste foreign exchange capital, increase the marginal cost of foreign exchange reserves, and sacrifice national consumption and investment. Holding foreign exchange reserves means temporarily giving up the use of a certain amount of real resources, thus losing the economic growth and the improvement of income level caused by these resource inputs. The opportunity cost of holding foreign exchange reserves is equal to the domestic capital productivity minus the investment income rate of holding foreign exchange reserves. In fact, excessive foreign exchange reserve is also a kind of idle fund, which forms the high opportunity cost of holding foreign exchange reserve and can not realize the optimal allocation of economic resources such as currency. The existence of high foreign exchange reserves has led to more serious 
inflationary pressure in China. According to common sense, in order to prevent China's foreign exchange reserves from exerting pressure on the appreciation of $\mathrm{RMB}$, it is necessary to convert them into RMB. There is no doubt that high foreign exchange reserves require a large amount of exchange in the operating mechanism, which is passive to China's own central bank in currency issuance. Finally, the existence of multiplier effect leads to further increase of inflation pressure, which also comes from China's high foreign exchange reserves. High foreign exchange reserves increase the difficulty and risk of reserve asset management. According to the world bank's survey of thousands of enterprises in Chinese cities, the return on investment of foreign-funded enterprises in China is very high at present. This shows that while China provides a lot of low interest financing to the United States at the expense of consumption and investment opportunities, foreign enterprises have made high profits in China. High foreign exchange reserves tend to intensify the friction between international trade. On the one hand, the increasing foreign exchange reserves show China's great achievements in commodity export and attracting foreign investment. On the other hand, it also exposes the imbalance of China's foreign trade development, which leads to the increase of economic friction between China and many countries, mainly with developed market economy countries, and the pressure of China's trade policy and foreign exchange policy is multiplied.

\section{SUGGESTIONS ON POLICIES}

\subsection{Appropriate reduction of foreign exchange reserves}

China should appropriately reduce its foreign exchange reserves and control its size. In this process, China must try to improve the income of low-income people from the social level, stimulate consumption and expand domestic demand. At the same time, China should use foreign exchange reserves to purchase strategic materials and establish a reserve system in case of emergency.

\subsection{Promote the reform of exchange rate system}

We will promote reform of the exchange rate system. Only if the exchange rate system can cooperate with the existing operation mechanism of high foreign exchange reserves, can China's expectation of RMB appreciation and the steady development of national economy be guaranteed. To ease the inflation pressure brought by foreign exchange in the process is also a major solution from the channel. China's decisions on its future currency regime should pay primary attention to China's own circumstances - not to one-size-fits-all prescriptions. Given the still fragile state of China's banking system, the capital-account decision should be delinked from the currency regime decision. All things considered, two-stage currency reform is better than the alternatives, because it reduces China's current internal and external imbalances. Moreover, it promotes the right sequencing of reforms within China and contributes to the timely correction of payments imbalances abroad. In addition, it moves monetary policy independence and capital-account liberalization in the desired direction in the long term [4].

\subsection{Reform of foreign exchange system}

In terms of foreign exchange management policies, the compulsory foreign exchange settlement and sale system can be phased out and the voluntary foreign exchange settlement and sale system can be implemented. The exchange system of willing settlement and sale can make part of the foreign exchange revenue be stored and remitted to the people, effectively distribute the foreign exchange reserves, and reduce the excessive pressure on the scale of foreign exchange reserves. In addition, China's accession to the WTO also requires the foreign exchange system to change to the willing foreign exchange settlement and sale system, so as to achieve the same national treatment of Chinese enterprises and foreign enterprises in the use of foreign exchange, and achieve fair competition.

\subsection{Balance of payments}

While fully recognizing China's great achievements in foreign trade and utilization of foreign capital, China's balance of payments management should be further improved. First of all, China should strengthen the management of capital projects. After RMB is convertible under current account, its long-term goal is to be convertible under capital account. Therefore, it is necessary to standardize the management of capital account in China's balance of payments, especially the management of short-term capital account. Secondly, China's balance of payments statistics should be strengthened to prevent foreign exchange loss. For example, we should speed up the reform of international balance of payments statistical survey methods, further improve the sampling survey of trade credit, adopt the advanced statistical concepts and methods in the world, boldly adopt the sampling survey method to collect relevant statistical information, establish a scientific and long-term data collection system, strengthen the sampling survey of service trade such as transportation revenue and tourism expenditure, and improve the comprehensive survey and sampling, etc Methods combined with the level of application, the channels of collecting balance of payments statistical data were widened [5].

\section{CONCLUSION}

Research results: China's huge foreign exchange reserve scale shows China's economic strength. On the one hand, it enhances China's ability to adjust the balance of payments, stabilize the RMB exchange rate, resist international financial risks and maintain economic stability, and is conducive to maintaining China's international reputation and improving China's 
international financing ability. However, on the other hand, it has brought negative effects such as high cost and low efficiency of resource occupation, RMB appreciation and increasing pressure of domestic inflation. Therefore, it is particularly important to determine the appropriate scale of foreign exchange reserves.

The inadequacies of the paper: because of the length of the paper, it did not refer to the relevant theories of foreign exchange reserves at home and abroad and the analysis of the current situation of China's foreign exchange reserves, combined with China's economic reality and the impact of the international environment, selected variables and used the econometric model to study the influencing factors of China's foreign exchange reserves. If the data is relatively perfect, it will make the structure of this paper more complete to give a certain econometric model.

What is worth studying: in terms of China's current high foreign exchange situation, based on the analysis of China's current foreign exchange reserves and the theory and application of appropriate scale of foreign exchange reserves at home and abroad, combined with China's economic reality, China can choose the influencing factors of foreign exchange reserves, and finally get an ideal regression model through various tools and methods. Through this model, some useful conclusions are drawn, which provide a good basis for analyzing foreign exchange reserves and making various decisions, and have important practical significance.

\section{ACKNOWLEDGMENT}

First and foremost, I would like to show my deepest gratitude to my teachers and professors in my university, who have provided me with valuable guidance in every stage of the writing of this thesis. Further, I would like to thank all my friends and roommates for their encouragement and support. Without all their enlightening instruction and impressive kindness, I could not have completed my thesis.

\section{REFERENCES}

1. R.R. Zou. Analysis of the impact of China's foreign exchange reserves on the macro economy, China Economic and trade guide, 2011 (02): 64-65

2. W. He, "The Influential Factors of China's Foreign Exchange Reserves," 2010 International Conference on Management and Service Science, Wuhan, 2010, pp. 1-4.

3. Y. H. Xu and C. Chen. Source structure and cause analysis of China's high foreign exchange reserves, Academic circles, 2008 (2): 151-159

4. M. Goldstein. Adjusting China's Exchange Rate Policies, Working Paper Series, 2004(WP04-1).

5. Z. M. Meng. The development process, problems and suggestions of China's balance of payments statistics, Financial circles, 2009 (11): 98-99 